\title{
PRIMARY MALIGNANT MELANOMA OF THE URINARY BLADDER: CASE REPORT
}

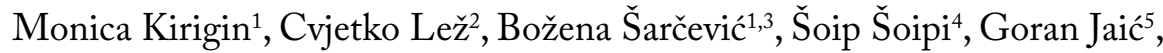 \\ Monika Ulamec ${ }^{1,3}$ and Božo Krušlin ${ }^{1,3}$
}

${ }^{1}$ Ljudevit Jurak Department of Pathology, Sestre milosrdnice University Hospital Centre, Zagreb, Croatia;

${ }^{2}$ Department of Pathology, Zabok General Hospital, Zabok, Croatia; ${ }^{3}$ Department of Pathology,

School of Medicine, University of Zagreb, Zagreb, Croatia; ${ }^{4}$ Department of Urology, Sestre milosrdnice University Hospital Centre, Zagreb, Croatia; ${ }^{5}$ Department of Urology, Zabok General Hospital, Zabok, Croatia

SUMMARY - Primary malignant melanoma of the urinary bladder is rare, with only 20 cases reported to date. We present a case of an 87-year-old woman with multiple comorbidities who presented with advanced urinary bladder neoplasm. Histopathologic analysis suggested melanoma of the urinary bladder. No previous or concurrent diagnosis of cutaneous melanoma was documented. The patient underwent transurethral resection of the tumor before and during hospitalization at our hospital but died shortly after due to widespread disease. Autopsy was not performed.

Key words: Urinary bladder; Melanoma; Urinary bladder neoplasms - surgery; Urologic surgical procedures - methods; Case reports

\section{Introduction}

Primary melanoma of the urinary bladder is exceedingly rare, with only 20 cases reported to date ${ }^{1}$. It accounts for less than $0.2 \%$ of all melanomas and has occurred within the range of 34-84 years, with mean age of 62 years at diagnosis ${ }^{1,2}$. The etiology and risk factors are largely unknown. Most cases of malignant melanoma of the urinary bladder are metastatic from a distant primary site, commonly of cutaneous origin ${ }^{1}$. We report a patient with primary malignant melanoma of the urinary bladder.

\section{Case Report}

An 87-year-old woman with multiple comorbidities presented to an outside urologist with gross hematuria and urinary incontinence, and the clinical diag-

Correspondence to: Prof. Božo Krušlin, $M D, P h D$, Ljudevit Jurak University Department of Pathology, Sestre milosrdnice University Hospital Centre, Vinogradska c. 29, HR-10000 Zagreb, Croatia E-mail: bozo.kruslin@kbcsm.hr Received January 12, 2015, accepted February 15, 2017 nosis was urinary bladder neoplasm. Records at Zabok General Hospital revealed evidence of metastatic change to the surrounding lymph nodes and suspected metastases to the liver, including an enlarged left renal parenchymal cyst and demineralization of bone with vertebral compression fractures. Physical examination showed a palpable suprapubic tumorous mass measuring $20 \mathrm{~cm}$ in largest diameter. Electroresection was

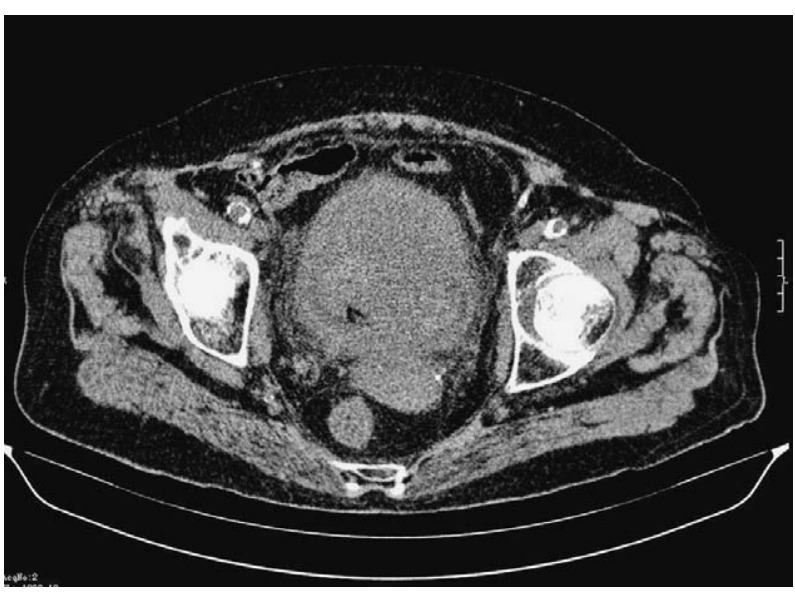

Fig. 1. CT finding of bladder neoplasm. 

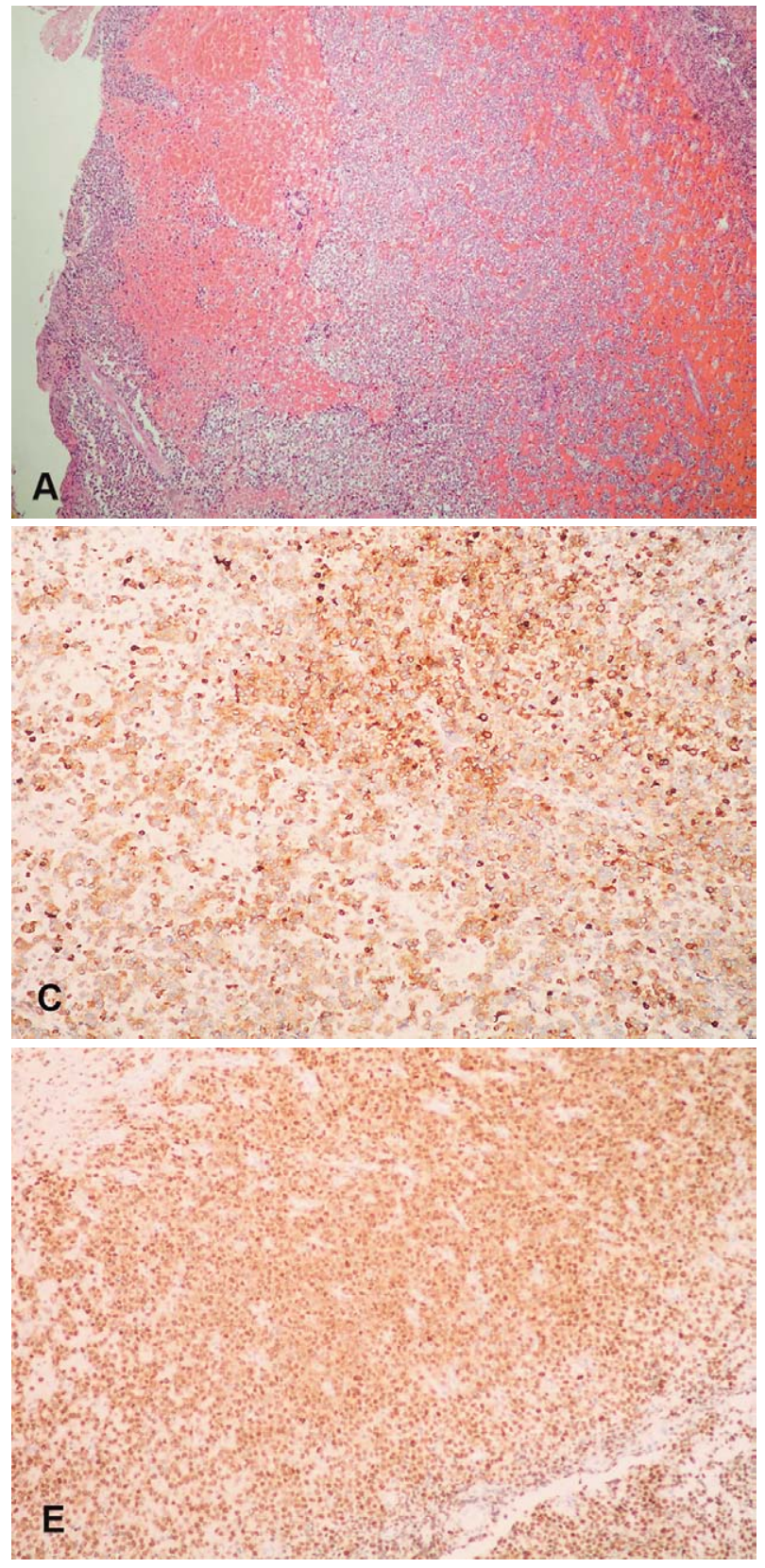

performed twice with reduction of tumor mass. The patient was then referred to our Tumor Department. No prior history of cutaneous melanoma was documented. Clinical and histopathologic analysis indicated primary malignant melanoma of the urinary bladder. The patient was soon after admitted to our Neurology Department after suffering a cerebrovascular insult, during which the course of treatment was complicated by episodes of gross hematuria with resultant anemia requiring erythrocyte replacement the-

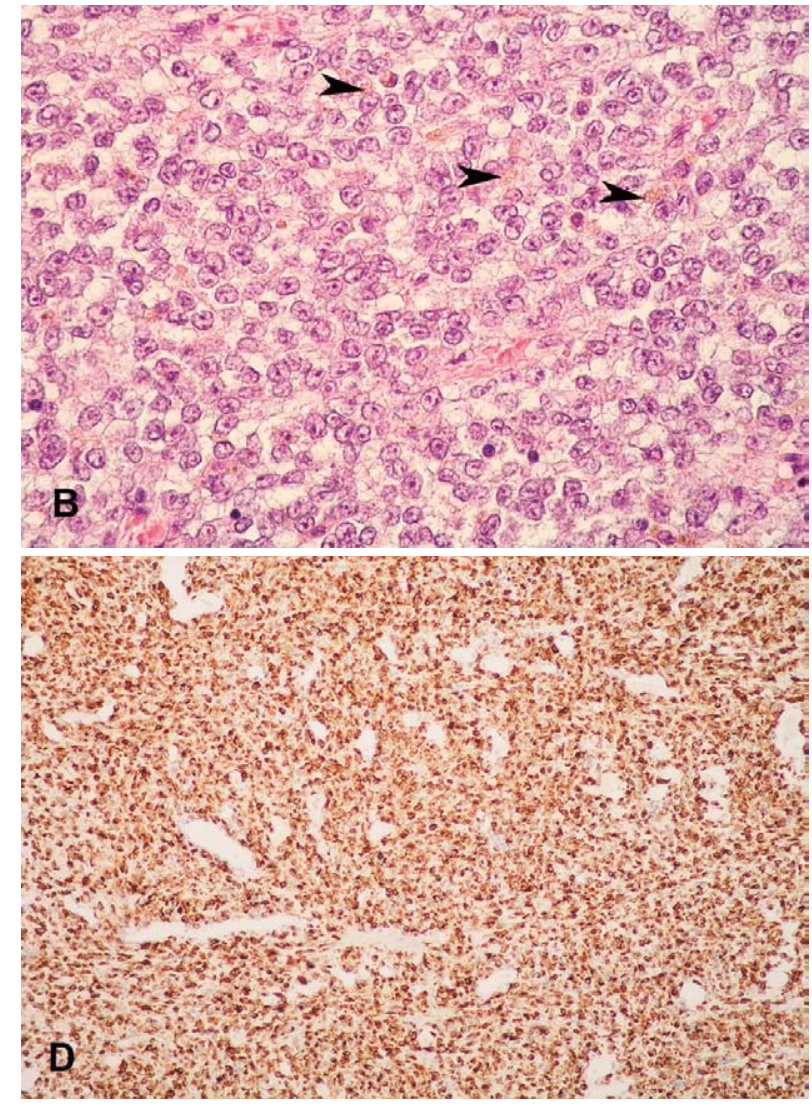

Fig. 2. Histologic appearance of the urinary bladder melanoma showing partly necrotic tumorous tissue composed of solid nests and groups of atypical, poorly differentiated, highly mitotically active cells with prominent nucleoli: $H E x 40(A) ; H E x 400(B)$; immunohistochemistry indicating positive reaction to $S-100(x 100)(C) ; H M B-45(x 100)(D)$; and MITF $(x 100)(E)$.

rapy. Partial transurethral resection (TUR) of the tumor was performed after multiple urology consults. The patient died two weeks later. No autopsy was performed.

\section{Pathological findings}

Pathological analysis of transurethrally resected tissue revealed partly necrotic tumorous tissue composed of solid nests and groups of atypical, poorly differentiated, highly mitotically active cells with promi- 
nent nucleoli. Immunohistochemistry indicated negative reaction to $\mathrm{CK} 7, \mathrm{CK} 20$ and $\mathrm{PAN}-\mathrm{CK}$, and positive reaction to S-100, HMB-45, tyrosinase and MITF. Histological and immunohistochemical analysis confirmed malignant melanoma of the urinary bladder.

\section{Discussion}

Primary malignant melanoma of the urinary bladder is a rare neoplasm ${ }^{3,4}$. The most common presenting symptom is gross hematuria, which suggests advanced disease. Other symptoms include dysuria, urgency, nocturia, frequency or urinary retention depending on tumor location and invasiveness. In eleven of 20 reported cases patients were female ${ }^{1}$. Cystoscopy and transurethral biopsy is the primary method of diagnosis. Primary cutaneous melanoma metastatic to the bladder is relatively common, affecting $18 \%$ of patients who die from metastatic melanoma ${ }^{1,4}$. Ainsworth et al. have proposed criteria to consider bladder melanoma a primary lesion: (1) detailed history and physical examination of the patient to rule out active or regressed cutaneous, ocular, and other visceral primary melanoma, and (2) pattern of recurrence should be consistent with the region of initial malignant melanoma ${ }^{1-3,5}$. Clinical staging involves a combination of radiographic assessment for metastasis, TUR and biopsy of the tumor, and pathologic assessment ${ }^{1}$. Primary melanoma of the bladder seems not to manifest itself until the disease is advanced ${ }^{1}$, as in our patient. Most patients die from metastatic disease within 3 years after initial diagnosis ${ }^{1,2}$. First-line treatment is surgery, which includes TUR, partial cystectomy and radical cystectomy depending on tumor stage $e^{1,2,5}$. Additional therapeutic options include radiotherapy, chemotherapy and immunotherapy ${ }^{2,5}$. It is reasonable to perform TUR and administer immune- or chemotherapy according to the patient's ability to tolerate medical treatment ${ }^{1}$. Chemotherapy options include platinum-based regimens such as cisplatin/carboplatin with paclitaxel, while immunotherapy options include ipilimumab, or high-dose interleukin 2 in patients with excellent performance status. Radiation therapy might be considered for palliative purposes in patients with primary bladder melanoma ${ }^{1}$. Delayed diagnosis combined with locally advanced stage of the disease at diagnosis results in poor prognosis, regardless of treatment approach $^{1}$. Poor prognosis in reported cases could be explained by tumor invasion of the muscle layer ${ }^{2,3,5}$. Radical treatments should be avoided in patients who are poor surgical candidates due to significant treatment-related morbidities and high risk of recurrence ${ }^{1}$. Malignant melanoma of the urinary bladder remains a therapeutic challenge to urologists ${ }^{1}$.

\section{References}

1. Truong H, Sundi D, Sopko N, Xing D, Lipson EJ, Bivalacqua TJ. A case report of primary recurrent malignant melanoma of the urinary bladder. Urol Case Rep. 2013;1:2-4, http://dx.doi: 10.1016/j.eucr.2013.10.002.

2. Pacella M, Gallo F, Gastaldi C, Ambruosi C, Carmignani G. Primary malignant melanoma of the bladder. Int J Urol. 2006; 13:635-7.

3. Ainsworth AM, Clark WH, Mastrangelo M, Conger KB. Primary malignant melanoma of the urinary bladder. Cancer. 1976;37:1928-36.

4. Das Gupta T, Grabstald H. Melanoma of the genitourinary tract. J Urol. 1965;193:607-14.

5. El Ammari JE, Ahallal Y, El Fassi MJ, Farih MH. Primary malignant melanoma of the urinary bladder. Case Rep Urol. 01/2011;2011:932973, http://dx.doi: 10.1155/2011/932973.

Sažetak

\title{
PRIMARNI ZLOĆUDNI MELANOM MOKRAĆNOG MJEHURA: PRIKAZ SLUČAJA
}

\author{
M. Kirigin, C. Lež, B. Šarčević, Š. Šoipi, G. Jaic, M. Ulamec i B. Krušlin
}

Primarni melanom mokraćnog mjehura je rijetka bolest, s 20-ak opisanih slučajeva u literaturi. U ovom radu prikazujemo 87-godišnju bolesnicu s brojnim komorbiditetima, a koja se javila u našu bolnicu s uputnom dijagnozom proširene tumorske bolesti mokraćnog mjehura. Patohistološka analiza otkrila je melanom mokraćnog mjehura, a treba istaknuti da bolesnica nikada nije imala dijagnosticiran melanom kože. Bolesnica je liječena transuretralnom resekcijom prije i tijekom hospitalizacije u našoj bolnici, gdje je nakon kraćeg vremena i preminula zbog uznapredovale bolesti. Obdukcija nije učinjena.

Ključne riječi: Mokraćni mjehur; Melanom; Mokraćni mjehur, tumori - kirurgija; Urološki kirurški postupci - metode; Prikazi slucaja 